\title{
Aşağılık Karmaşasına Hapsolmuş Bir İsim: Ahmet Haşim
}

\author{
Dr. Öğr. Üyesi Hayrunisa Topçu \\ Hacettepe Üniversitesi Edebiyat Fakültesi \\ Türk Dili ve Edebiyatı Bölümü \\ nisa@hacettepe.edu.tr
}

Öz

Türk edebiyatının önde gelen isimlerinden olan Ahmet Haşim, şair ve nasir kimliği ile edebiyat araştırmacılarının her dönem ilgisini çekmiştir. Annesinin yoğun sevgisi ve ilgisi altında geçen çocukluk yılları, İstanbul'a gelip Galatasaray Lisesi'ne başlamasının ardından yeni bir sosyal çevreye uyum sağlama sürecinin sancıları, çirkinlik saplantısı, şairin kendisi için olduğu kadar edebiyat araştırmacıları için de zengin bir malzeme yığını oluşturmaktadır. Nitekim Haşim'in aile ortamı ve ergenlik yıllarındaki duygusal zorlanmaları, onun hem yaşamında hem de düzyazı ve şiirlerinde derin izler bırakmıştır. Bu izlerin tespit edilebilmesi için Viyanalı psikiyatrist Alfred Adler'in aşağılık karmaşası kavramından yararlanılmıştır. Sözü edilen kavram aracılığıyla hem sanatçının kişiliğine hem de eserlerine ışık tutulmaya çalışılmıştır. Aslında her insanda, var olmanın sonucunda ortaya çıkan eksiklik duygusu; kişinin becerileriyle, yapabildikleriyle bir motivasyon kaynağına dönüşmezse aşağılık kompleksi halini alır. Kişi, kendisini değersiz ve yetersiz hisseder. Bu duygudan kurtulabilmek içinse öfke, kibir, hırs, gurur gibi saldırganca tavırlar geliştirir veya kendisini ayrıcalıklı hissedebilmek için insanlardan kaçar. Çocukluğunu annesinin koruyucu sevgisi ile babasının mesafeli tavrı arasında geçiren Haşim aşağılık duygusundan bir türlü kurtulamaz, çünkü babası tarafından ihmal edilmiş, annesi tarafından ise abartılı bir sevgi ve ilgiyle büyütülmüştür. Bunun sonucunda kendisini üstün hissedebilmek için saldırganca davranışlar geliştirmiş ve insanlardan uzaklaşmıştır. Bu çalışmada, Ahmet Haşim'in hayatından ve eserlerinden hareketle ondaki aşağıllık kompleksinin nedenleri ve görünümleri tespit edilmeye çalışılmıştır.

Anahtar Kelimeler: Aşağılık kompleksi, çirkinlik saplantısı, Alfred Adler, Ahmet Haşim. 


\title{
A Literary Figure Trapped in an Inferiority Complex: Ahmet Haşim
}

\begin{abstract}
Ahmet Haşim, one of the leading figures of the Turkish literature, has always been of particular interest as a poet and prosaist to literary literature researchers. His childhood years spent with his mother's intense love, his painful adaptation to a new social environment after moving to İstanbul and starting Galatasaray High School, and his ugly duckling complex offered him and literature researchers a great wealth of material. Indeed, Haşim's family setting and emotional challenges in the adolescence left deep traces in his life, prose, and poetry. To discover these traces, this study employed the concept of inferiority complex coined by Viennese psychiatrist Alfred Adler. Using this concept, the study sought to shed light on both the personality of the artist and his works. Every person has the existential sense of lack which turns into an inferiority complex if it is not transformed into a source of motivation through abilities and capacities. Consequently, people feel worthless and incompetent. Then, they exhibit aggressive attitudes like anger, arrogance, ambition, and pride to get rid of this feeling or stay away from others to feel privileged. Haşim did not manage to overcome the feeling of inferiority. Because he was neglected by his father and raised by an exaggerated love and care of his mother. As a result, he developed aggressive behavior and stayed away from people to feel superior. This study attempted to identify the causes and manifestations of Ahmet Haşim's inferiority complex.
\end{abstract}

Keywords: Inferiority complex, ugly duckling complex, Alfred Adler, Ahmet Haşim. 


\section{GíRiş}

Bireysel psikoloji, Viyanalı hekim Alfred Adler tarafından geliştirilen, psikoloji alanına ait bir alt disiplindir. Tıp eğitimini Viyana Üniversitesi'nde yapan Adler'in esas uzmanlık alanı göz hastalıklarıdır. Çalışmalarına daha sonra psikiyatri alanında devam eden ve aynı zamanda psikanalizin babası olarak anılan Sigmund Freud'un öğrencisi olan Adler, bir dönem Psikanalitik Derneği'nin başkanlığını yapmıştır. Fakat görüşleri nedeniyle dernek üyeleriyle yaşadığı anlaşmazlıktan dolayı dernekten ayrılmış ve bu süreçte Freudçu psikanalizden kopmuştur. Nitekim bir süre sonra da kendisiyle özdeşleşecek olan bireysel psikoloji disiplinini ortaya atmıştır. Geçtan Adler'in psikoloji dünyasına getirdiği yenilikler bahsinde ilk olarak toplumsal unsurlardan bahseder. Adler'in toplumsal etkenlere verdiği önem sosyal psikolojinin önünü açar. Geçtan, ikinci olarak ise onun "yaratıcı benlik" kavramından bahseder. Bu kavramı şu cümlelerle açılar: "Benlik, sürekli olarak bireye doyum sağlayacak yaşantıları arar, eğer bunlar dış dünyada bulunamazsa, yaratmaya çalışır." (1993: 53). Son olarak ise Adler'in ortaya attığı "kişiliğin tekliğì" düşüncesinden bahsedilir. Bu düşünceye göre karakter özellikleri açısından değerlendirildiğinde her insan kendine özgü ve tektir. Bu nedenle de bir insanın davranışları onu başkalarından ayıran, kendisine ait yaşam biçiminden izler taşır. Böylelikle Adler'in bakış açısı, insanı toplumsal ve bireysel etkenler çerçevesinde ele almış olur. Psikanalitik yaklaşımın aksine insanın bilinçli bir varlık olduğu gerçeğinden hareket eden bu görüş, kişinin eksikliklerinin, amaçlarının bilincinde olduğunu söyler. Buradan yola çıkarak insanı harekete geçirecek itici gücün, onun geçmişi değil geleceğe yönelik beklentileri olduğuna inanır (Geçtan 1993: 53). Adler'in, kişinin karakterinin tek ve benzersiz olduğu düşüncesine dayanarak yaptığ çalışma ve değerlendirmeler, psikanalizi bilinçaltına bağlı olmaktan çıkarmış, söz konusu disiplinin daha bütüncül bir bakış açısıyla tanımlanmasını sağlamıştır.

Adler'in "İnsan olmanın aşağıllk duygusuna kapılmak olduğunu uzun zamandan beri ısrarla belirtmekteyim." (2002: 82) ifadesi, sözü edilen itici gücün kaynağının aşağılık duygusunu olduğunu ortaya koyar. Çünkü her insanda varoluşuyla beraber gelen bir yetememe hali veya eksiklik durumu vardır ve insan, aslında yaşamına bu acizliği fark ederek başlar. Bu eksiklik hali onun ölümüne dek varlığını sürdürür. Fakat eksiklik, bir diğer adıyla aşağılık duygusu, kişinin doğuştan gelen fiziksel özelliklerinden kaynaklanan veya toplumsal iletişimi neticesinde ortaya çıan yetersizlik duygusu ile kompleks haline dönüşür. "Yetersizlik duygusu inatçı bir hastalıktır ve en azından bir iş yapıncaya, bir ihtiyaç karşılanıncaya veya bir tansiyon azalıncaya kadar devam eder. (...) Bu problemlerin çözümünün yeterli bir sosyal duyguyu, tüm hayatla sıkı bağlılığı, başkalarıla bir arada bulunmak ve işbirliği yapmak yeteneğini istediğini göreceğiz." (Adler 2002: 59). Fakat çözüme kavuşturulamayan aşağıllk duygusu, çeşitli nedenlere kronik hale gelir ve aşağılık kompleksine dönüşür. Geçtan, bu noktada kişinin aşağılık kompleksini yenebilmek için çabalamaya başlayacağını ve uyumsuz davranışlar gösterebileceğini belirtir (1993: 54). Adler, uyumsuz davranışlar olarak nitelenen bu hareketleri, acı çeken ruhun kendisini iyileştirmek için geliştirdiği savunma mekanizması olarak görür. Üstünlük çabası olarak da tanımlanan bu savunma mekanizması, kendisini herkesten üstün tutabilmek ve aşağılık kompleksini yenebilmek için başkalarının hayatlarına karşı saldırgan davranışlar, boş gurur, kıskançlık ve küçümseyici tavırlar içerebilir (Adler 1994: 186-189). Yani, üstünlük çabası başlığı altında verilen bu uyumsuz davranışların kökenleri, çoğunlukla kişinin geçmişinde aşağılık kompleksiyle bağlantılı olarak bulunabilir. $\mathrm{Bu}$ üstünlük çabası aynı zamanda yaratıcılığın da kaynaklarından birini oluşturur. May, Yaratma Cesareti adlı çalışmasında Adler'le yaptığı konuşmayı şu sözlerle anlatır: “Oturma 
odasındaki konuşmasında yaratıcılığı telafi etme olarak (compensation) kuramlaştırmasına değindi insanlar, sanatı ve bilimi ve kültürün diğer yanların yetersizliklerini telafi etmek için üretirler." (May 2018: 61). Bu durumda sanatçılardaki yetersizlik duygusu hem aşağılık kompleksine zemin hazırlar, hem de ondaki yaratıcıllğı ortaya çıkaran ve besleyen bir unsur haline gelir. Nitekim sözü edilen görüşlerden yola çıkılacak olursa, bu yazının konusu olan Ahmet Haşim'in edebiyat alanındaki yaratıcılığının kaynaklarından biri de başa çıamadığı yetersizlik duygusudur.

Türk şiirinin yenileşmesinde önemli bir rol üstlenen ve eserleriyle olduğu kadar karakteriyle de edebiyat dünyasının dikkat çekici isimlerinden birisi olan Ahmet Haşim, Alfred Adler'in bireysel psikoloji bağlamında geliştirdiği aşağılık karmaşası için ilginç özelliklere sahip bir isimdir. Ahmet Haşim'in çocukluğu babasının memuriyeti nedeniyle Arabistan vilayetlerinde geçer. Onu bu dönemde en çok etkileyen şey ise annesi ile Dicle Nehri kenarında yaptığı gezintilerdir. Sonraki yıllarda şiirlerinin ilham kaynağ gezintiler onun aile yapısı hakkında da bilgiler verir. Babasından neredeyse hiç söz etmeyen Ahmet Haşim, annesine âdeta tutkuyla bağlıdır ve çocukluğunda zamanının büyük bir kısmını annesi ile geçirdiği anlaşılmaktadır. Babasının bu eksikliği, o on iki yaşına gelince daha da somutlaşır. Annesi Sâre Hanım, Haşim sekiz yaşlarında iken vefat edince, babasıyla il il dolaşan Ahmet Haşim, ortaokul çağına gelince babası tarafından önce Numûne-i Terakkî Mektebi'ne, sonra da Galatasaray Lisesi'ne verilir. Türkçesinin bozuk ve aksanlı olması nedeniyle arkadaşlarının alaycı esprilerine maruz kalan Ahmet Haşim'in anne özlemi ve baba eksikliğine bozuk Türkçesinden kaynaklanan aşağılık duygusu da eklenir. Bu arada kendisinin dış görünüşünden duyduğu memnuniyetsizlik de onun aşağılık duygusunu besler. Haşim çirkin bir yüzü olduğuna dair kesin bir kanaate sahiptir. Şiirlerinde ve sohbetlerinde ara ara bu durumdan bahseder. Böylelikle çocukluğuna dek uzanan çeşitli nedenler, Ahmet Haşim'in derin bir aşağılık karmaşasına hapsolmasına sebep olur. Bu durumun etkileri gerek özel yaşamında gerekse eserlerinde görülebilir.

Aşağılık Karmaşasına Hapsolmuş Bir İsim: Ahmet Haşim isimli bu çalışmada, psikanalitik edebiyat kuramının çift yönlü çalışma ilkesinden faydalanılacaktır. Nitekim Moran, bu eleştiri yönteminin "1. Eserleri aydınlatmak için sanatçının hayatın, kişiliğini incelemek, 2. Sanatçının psikolojisini, kişiliğini aydınlatmak için eserlerini bir belge gibi kullanmak." (2004: 132) şeklinde olmak üzere iki türlü kullanılabileceğini söyler. Bu çalışmada hem Ahmet Haşim'in karakterini görünür hale getirmek için eserlerinden faydalanılmış hem de eserlerinin analiz edilebilmesi için karakteri, Alfred Adler'in aşağılık karmaşası bağlamında değerlendirilmiştir. Çalışmada, Ahmet Haşim'in şiirlerinin ve düzyazılarının tamamı dikkate alınmış, gerek onların aydınlatılmasında sanatçının yaşamına başvurulmuş, gerekse Ahmet Haşim' in psikolojisi ile ilgili çıkarımlar eserlerinden yola çıkılarak yapılmıştır.

\section{Aşağılık Karmaşasının Ahmet Haşim'in Şiirleri ve Düzyazılarındaki İzleri}

Alfred Adler, her çocuğun doğumundan itibaren derin veya yüzeysel biçimde aşağılık duygusu ile yüz yüze geldiğini söyler. Bunun nedeni, çocuğun doğuştan gelen organ eksikliği gibi organik kusurları olabileceği kadar, bir yetişkinin yardımı olmadan en temel ihtiyaçlarını karşılayamaması gibi sıradan bir durum da olabilir (Adler 1994: 180). Her ne kadar bu süreç, çocuğun yetersizlik duygusunu yenebilmek için itici bir güç oluştursa da onun kendine olan inancını perçinlemez ise travmatik bir hal alarak komplekse dönüşür ve sonraki yıllarda farklı görünümlerde ortaya çıkabilir. Ahmet Haşim'in gerek eserlerinde gerekse özel yaşamında görülen bu kompleksin izlerini çocukluk ve ilk gençlik yıllarında 
aramak doğru olacaktır. Daha önce de bahsedildiği üzere onun sekiz yaşlarına kadar annesiyle olan ilişkisi sonraki yıllarda kadınlarla olan ilişkisini büyük ölçüde şekillendirmiştir. Annesinin ona olan yakın ilgisi, zamanının büyük bir kısmını verem hastası olan annesiyle geçirmesi, ardından annesinin vefat etmesi Haşim'in ruhsal dünyasını alt üst etmiştir. Bu arada baba figürünün eksikliğinin veya onunla olan iletişiminin kopukluğunun Haşim'i annesine yaklaştırdığı, annesinin vefatından sonra da annesine olan özlemini artırdığı yönünde bir tahminde bulunulabilir. Bu süreçte yaralanan ruhunu, sonraki yıllarda, yaşamına giren kadınlarda annesinin kendisine karşı gösterdiği ilgi ve özeni arayarak tamir etmeye çalışmıştır. Fakat kendisini, tanıştı̆̆ı veya gözlemlediği kadınların yanında yetersiz hissetmekten bir türlü alıkoyamamış bu durum da çeşitli saldırgan davranışlar olarak şeklinde ortaya çıkmıştır. Haşim'in aşağılık kompleksine dayanaklık edebilecek ikinci çıkış noktası ise dış görünüşünden duyduğu memnuniyetsizliktir. Kendisini çirkin bir insan olarak kabul eden Haşim, bu durumun yarattığ 1 özgüvensizlikten bir türlü kurtulamaz. Kadınların bu nedenle kendisini beğenmeyeceğini düşünür. Bu ruh hali de onlara karşı hırçınlaşmasına sebep olur. Böylelikle onun annesine duyduğu bitmeyen özlemi dış görünüşünden duyduğu memnuniyetsizlikle birleşince, şairin kadınlarla olan ilişkisi oldukça karmaşık bir hal alır. Ahmet Haşim'in ergenlik yıllarında yaşadığı dil sorunu da onda derin izler bırakmış ve şairdeki aşağılık kompleksini beslemiştir. Çocukluğunu Arabistan vilayetlerinde geçirmesi ve Türkçeye hâkim olmaması onun arkadaşları arasında alay konusu olmasına neden olmuştur. Bu durum onun yeni girdiği sosyal çevreye uyum sağlamasını zorlaştırmış ve kendisini yalnız hissedip insanlardan uzaklaşmasına yol açmıştır. Ahmet Haşim'in çocukluk ve ergenlik yıllarında yaşadığı olaylar, ondaki aşağılık duygusunun aşağılık kompleksine evrilmesine ve sanatçının bazı uyumsuz davranışlar geliştirmesine neden olmuştur. Yani bahsi geçen bu olaylar aslında aşağılık kompleksinin kıvılcımı olmuş fakat kompleksin Ahmet Haşim'in hayatındaki etkileri ise farklı şekillerde gözlemlenmiştir. Yazının ilerleyen bölümlerinde gerek bu olayların ortaya çıkışları gerekse etkileri, sanatçının şiirlerinden ve düzyazılarından hareketle ayrıntılı bir şekilde açıklanmaya çalışılacaktır.

\section{Kadınlarla Olan İlişkisi}

Ahmet Haşim'in başta annesi olmak üzere kadınlarla olan ilişkisi iç dünyası konusunda birçok ipucu barındırır. Bu ipuçları onun gerek özel gerekse edebî yaşamında gözlemlenebilir. Kenan Akyüz de benzer bir değerlendirmede bulunarak "Bütün hareketlerine ve edebî faaliyetine tesir eden; içinde korkunç, sürekli ve hazîn ve huzûrsuzluk doğuran; onu tezâdlar ve aşırılıklar arasında kıvrandıran bu çapraşık dü̈̆̈̈mü kaderinin yavaş yavaş nasıl hazırladığını görebilmek için çocukluğunun ilk zamanlarına inmek icâb eder." (1985: 597) sözleriyle, şairin çocukluğunun edebiyat araştırmacıları için ne denli önemli olduğunun üzerinde durur. Babasının görevi nedeniyle, çocukluğu, Arabistan'ın çeşitli illerinde geçen şairi en fazla etkileyen yer, şüphesiz Bağdat ve Dicle Nehri kıyılarıdır. Dicle Nehri'nin kenarında verem hastası olan annesi ile yaptığı yürüyüşler onunla annesi arasında kuvvetli bir bağ inşa etmekle kalmamış, hasta bir kadını, ruhen hassas bir çocuğun tek sığınağı haline getirmiştir. Kenan Akyüz anneyle oğlu arasındaki ilişkiyi şu sözlerle ifade eder:

\footnotetext{
"Çok zeki ve hassâs bir çocuk olan küçük Hâşim, günlerini, sekiz yaşına kadar, yine hassâs ve hasta bir anne ile hâşin bir babanın arasında geçirir. Annesi, belki, bünyece mârizdi; fakat -şâir sonraları babasının sertliğinden ve şefkatsizliğinden şikâyet ettiğine göre- hastalanmasında, belki bedbaht bir izdivâcın da büyük bir hissesi vardır. Âile
} 
hayâtının bu hazîn huzursuzluğu, çocuğun bedenî ve rûhî gelişmesi üzerinde de te'sîrlerini göstermekte gecikmez. Bünyece mârizleşmeye yüz tuttuğu gibi, ruhunda da sarsıntılar belirmeğge başlar. Şefkate şiddetle muhtâc olan küçücük varlığı, babanın sertliği karşısında, sâdece, hasta bir annenin kırık kanadlarına sı̆̆ınır. Anne bütün ilgisini çocuğuna, çocuk da bütün sevgisini annesine bağlamıştır. Her akşam veya her gece, bu hasta anne ve çocuk, yalnız başlarına, Dicle'nin kıyısında gölgeler gibi sessiz sessiz dolaşırlar (Şi'r-i Kamer : O)." (1985: 598)

Kenan Akyüz'ün Ahmet Haşim'in babasıyla ilgili değerlendirmeleri dikkat çekicidir. Bu değerlendirmeleri doğrulayacak şiir, düzyazı veya anı yoktur. Fakat Suut Kemal Yetkin de, Haşim'in babasının sert mizacını vurgulamak için "Suçlu olduğu zamanlar, babasının kendisini odaya kapadığını söyleyivermiş idi." (1969: 66-67) ifadesini kullanır. Alptekin, annesinin vefatının ardından, babası Arif Hikmet Bey'in, Haşim yaklaşık dokuz yaşlarında iken yeniden evlenerek Revendus'a gittiğini belirtir (Alptekin 1985: 9). Nitekim Ayvazoğlu da Haşim'in anne ve babasının evliliğinden benzer bir bakış açısıyla söz eder.

\begin{abstract}
“(..) Hâş̧im, hemen ardından, mutluluğunun kaynağı olan annesinin gözleri için, Bir lâhza sevilmiş, unutulmuş keder-âlûd / Rüyâlı kadın gözleri diyor. Bu mısralardan hareketle, Sâre Hanım'ın Ârif Hikmet Bey'le evliliğinde hayal kırıkhı̆̆ına uğradı̆̆g, "bir lâhza sevil"dikten sonra ihmal edildiği, unutulduğ söylenebilir. Eşinde bulamadiğ mutluluğu küçük Hâşim'de arayan ve ona marazî bir sevgiyle bağlanan Sâre Hanım'ın en büyük zevklerinden biri, Bă̆dat'ın bunaltıcı yaz gecelerinde Dicle kıyılarında gezinmek ve mehtabı seyretmektir; arkadaşı ise elinden sıkı sıkı tuttuğu küçük ve hastalıklı oğlu..." (2012: 38)
\end{abstract}

Alıntıdan da anlaşılacağı üzere Haşim'in en yakın arkadaşı, annesi Sâre Hanım'dır. Genç kadın vaktinin çoğunu küçük oğluyla Dicle Nehri kenarında geçirmektedir.

Haşim'in aile yapısı ve çocukluğuyla ilgili kesin ve ayrıntılı veriler olmamakla birlikte yapılan değerlendirmelerden yola çıkıldığında, annesinin sarıp sarmalayan sevgisi ile babasının mesafeli ve katı tutumu arasında kalmış bir çocuk göze çarpar. Böyle bir ortamda Sâre Hanım, Ahmet Haşim'in tek sığınağı haline gelmiş, aralarında anne-oğul ilişkisinin ötesinde derin ve kuvvetli bir bağ ortaya çıkmıştır. Bu tablo Alfred Adler'in aşağı llık karmaşasının temeline oturttuğu nedenlerden iki tanesini akla getirir: ihmal edilme ve şımartılma. Adler, çözümlenmemiş bir aşağılık duygusunu ve başka insanlardan üstün olma isteğini çocuğun eğitilebilir olmasının önündeki engeller olarak kabul eder. Çünkü bu çocuklar hem doğa hem de diğer insanlar tarafından ihmal edildiklerine inanırlar. Yaşamları yapmak isteyip yapamadıklarıyla, yani yenilgilerle doludur (Adler 1994: 180). Bu noktada Ahmet Haşim'in babası ile olan mesafeli ilişkisini hatırlamak gerekir. Her çocuğun doğuştan getirdiği aşağılık karmaşasından kurtulabilmesi için ebeveynlerinin desteğine, onayına ve takdirine ihtiyacı vardır. Böylece çocuğun kendi kendine becerebildikleri önüne çıan engelleri aşması konusunda itici bir güç oluşturur. Fakat Haşim, babasının ilgisini yeterince hissedememiştir. Dolayısıyla onu yaptıkları için takdir edecek, yapmakta tereddüt ettikleri için de yüreklendirecek dayanaklardan biri eksiktir. Annesi ile arasındaki özel bağ, bu eksikliği telâfi etmek istercesine kuvvetlidir. Fakat bu bağın, "Bazıları sanki oyuncakmış, canlı bir bebekmiş ya da dikkatle gözetilmesi gereken değerli bir eşya imiş gibi görülmekte" (Adler 1994: 181) sözlerini doğrularcasına Haşim'in şımartılmasına neden olduğu düşünülebilir. Onu, sonsuz bir sevgi şefkat yumağına hapseden annesinin, Haşim'i aynı zamanda önüne çıkacak güçlüklerle mücadele edecek, bu güçlüklerin üstesinden gelebilmesi için yaşıtlarıyla işbirliği 
yapacak bir sosyal ortamdan mahrum bıraktığı söylenebilir. Ayrıca verem hastası olan Sâre Hanım'ı kaybetme korkusunun, Haşim'in yaşam karşısındaki acizliğini pekiştirdiği, böylece aşağılık karmaşasının Haşim üzerindeki etkisini artırdığı düşünülebilir. Çünkü fiziksel ihtiyaçlarını giderebilmek noktasında her çocuğun yaşadığı aşağılık karmaşasına, bir de annesini kaybetme korkusu ve bu hastalığ engellemek konusundaki acizliği eklenince Haşim'in yetersizlik hissi daha da kuvvetlenmiştir. Dolayısıyla Ahmet Haşim, aşağı llkk karmaşası ile başa çıkabileceği bir aile yaşantısı ve sosyal ortamda bulunmak yerine annesinin koruyucu kanatlarına sığınan bir çocuk olmuştur. Ahmet Haşim'in yetişkinlik yılları ve şiirleri onun çocukluğundan yola çıkılarak yapılan bu tespitleri destekler niteliktedir. Yani ihmal edilme ve şımartılma nedeniyle aşağılık karmaşasından aşağılık kompleksine dönüşen psikolojik durum ilerleyen yıllarda uyumsuz davranışlar olarak ortaya çıkar. Bu davranışlar ve duygular, kibir, kıskançlık, tiksinti, insanlardan kaçma, anksiyete ve çekingenlik şeklinde görülür.

Adler, insan doğasını ana hatlarıyla değerlendirdiği çalışmasında kadın ve erkeğin birbirlerine olan bakış açılarını ele alır. Bu noktada özellikle erkeklerin kadınlardan üstün olduğu inancı üzerinde durur ve bu algının neredeyse onlarca yıldır tüm toplumlar tarafından benimsendiğini vurgular. Sözü edilen algının kökenleri, erkeklerin anaerkil sistemleri reddetmelerine ve kadınları toplum içerisinde huzursuzluk kaynağı olarak görmelerine dek götürülebilir. Bu düşünce, zaman içerisinde erkeklerle aynı işleri yapan kadınların daha düşük ücretler karşılığında çalıştırılmaları, onların günlük yaşamda ikinci sınıf vatandaş yerine konulmaları gibi davranışlarla pratiğe dökülmüştür (Adler 1994: 252253). Haşim de mensup olduğu toplumun bu algısından nasibini almış ve 19. yüzyılda gerek sosyal yaşamın gerekse çalışma hayatının her alanında yerini almaya başlayan kadının yükselişine zaman zaman hayretle zaman zaman da öfke ve tiksintiyle bakmıştır. Ne var ki onun bu davranışlarını açıklamak için geleneksel kadın algısının bir adım ötesine geçip Haşim'deki aşağılık kompleksine odaklanmak gerekir. Haşim'in, bu kompleksin kendisindeki etkilerini hafifletebilmek, bir anlamda telafi edebilmek için diğer insanlardan üstün hissedebilmeye, kendisini değerli kılmaya ihtiyacı vardır, bunu yapabilmek için de kadınları aşağılamıştır. Sözü edilen küçümseme duygusuna yer yer kibir ve tiksinti de eşlik etmiştir. Ahmet Haşim, Dreykul'da Kadın Modaları isimli yazısında kadına erkeğin aşkı üzerinden değer biçer.

“Ey, en küçük heveslerine esir olduğumuz kadınlar! Söylemezsiniz ama pekâlâ bilirsiniz ki, bütün varlığınız erkeğin size karşı duyacağı aşka bă̆lıdır. Erkeğin aşkı olmazsa, düşük omuzlu, kısa ayaklı, iri kalçalı, korkunç bir mahlûk şekline istihale etmenize mâni ne kalır? Erkek aşkına lisan veren dâhilerin, sihrengiz aynalar teşkil eden ulvî eserlerinde aksinizi gördüğ̈̈nüz içindir ki, kendinizi beğenirsiniz." (2014b: 66)

Haşim'e göre kadını tuhaf bir yaratık olmaktan kurtaracak şey, erkeğin ona duyduğu aşktır. Bu satırlarda hem açık bir aşağılama hem de yoğun bir kibir vardır. Haşim'in ruhunun derinliklerine işlemiş aşağılık kompleksinden bir nebze olsun kurtulabilmesi kendisinin diğer insanlardan daha üstün olduğunu hissetmeye ihtiyacı vardır, bunun yöntemlerinden biri de diğer insanları aşağılamaktır. Kendisini değerli bulabilmesi içinse kibre tutunur. "Kibirli insan hedefini diğer insanların değeri olarak belirler. Başka insanları alçaltarak üstünlük duygusu kazanma doğrultusunda bir girişimdir bu. Bir başka insanın değerinin kabul edilmesi bireyin kişiliğine hakaret olarak görülür." (Adler 2004: 161). Tiksinti de aşağılık kompleksi çerçevesinde kişide görülen duygulardan bir diğeridir. Adler'e göre 
hoşlanmamanın ardından gelen tiksinti sonucunda ortaya çıkan yüz buruşturma, aşağılamanın ve sorunu reddederek çözme girişiminin göstergesidir. Bu durum aynı zamanda tiksinti duyulan insandan veya olaydan uzaklaşmak için güvenilir bir bahane oluşturur (2014: 217). Ahmet Haşim, kadınlardan bahsettiği bazı yazılarında onları tiksindirici bulduğunu açıkça ifade eder. "Nice ilâhi başların pembe dudakları, her açılışta, dimağdan inen koca bir hamakat öküzüne yol veren bir kapı vazifesini görür. Bu itibarla bazı kadın başları, hakikatte, altın, elmas ve yakuttan yapılı tiksindirici birer belâhet medharıdır." (2014a: 51). $\mathrm{Bu}$ satırlarda Haşim kadınları küçümsemekle kalmaz, aynı zamanda onların ahmaklıklarından tiksinir. Tiksinti duygusunun, onun aşağılama duygusunu kuvvetlendirdiği dolayısıyla da üstünlük kurma çabasını artırdığı fark edilebilir. Öte yandan Adler'in yorumundan yola çıkılacak olursa, tiksinti duygusu aynı zamanda Haşim'in kadınlardan uzak durma nedenlerinden birini de oluşturur. Haşim'in kadınlardan kaçması ile ilgili ayrıntılar çoğunlukla yakın arkadaşları Abdülhak Şinasi Hisar ve Yakup Kadri Karaosmanoğlu'nun anılarında yer alır. Abdülhak Şinasi Hisar, Haşim'in evlenmek üzere bir hanımla tanışmasının ardından ortadan kaybolmasını şu cümlelerle anlatır:

“Fakat hayret! Alt katta görülmüş olan Haşim ortadan kayboluvermiş. Hizmetçiler kapıyı açıp çıktığını söylemişler. Tanıdığımız hanım da aile erkânına mahcup, mazeretlerini, bir yanlışlık olduğunu kabul ettirmek istemiş. Sonra Haşim'e sormuşlar: Aşă̆ı kattaki genç kızın annesinin ne acûze olduğunu gördüm. Birkaç sene sonra kendisinin de ne olacă̆ın anlayınca korkudan kaçtım! diye cevap vermiş." (1963: 127-128)

Başından buna benzer birden fazla olay geçen Haşim, türlü bahanelerle evliliğin eşiğinden döner. Karaosmanoğlu (2006: 131), bu bahanelere örnek olarak Haşim'in nişanlısının konuşurken boynunun bir ibriğe benzemesini gösterirken, Hisar (1963: 129), müstakbel kayınvalidesinin Haşim'in cebine yiyecek koymasından da ayrılık nedenlerinden biri olarak bahseder. Böylece Haşim çeşitli bahanelerle, evlenmek ümidiyle bir araya geldiği kadınlardan kaçar. Adler, bu durumun psikolojik nedenlerini şu şekilde anlatır:

\begin{abstract}
“Geri çekilme ve yalıtılmışlık çeşitli biçimlerde ortaya çıkar. Toplumdan kaçan insanlar ya hiç konuşmaz ya da çok az konuşurlar. Başka insanlarm gözünün içine bakmazlar ve onlarla konuştuğumuzda dikkatlerini bize yöneltmezler. (...) Tüm bu yalıtılmışlık düzeneklerinin altında bir hırs ve kibir eğiliminin gizli olduğunu görürüz. Bu insanlar kendileriyle toplumun geri kalanı arasındaki farkları vurgulayarak kendilerini diğerlerinin üstüne çıkarmaya çalışırlar; ama kazanabilecekleri en büyük şey hayali bir görkemdir. Bu sosyal sürgünlerin görünürde zararsız tutumlarmda kavgacı bir düşmanlığın varlığı apaçık bir biçimde sergilenir." (2004: 186-187)
\end{abstract}

Haşim'in kadınlardan kaçması bir anlamda kendisini ayrıcalıklı hissettiği konumu korumak içindir. Çünkü bu sayede üstünlük halini koruması mümkün olur. Fakat özellikle düzyazıları da dikkate alındığında kadınları tarif ederken kullandığı sözcüklerde onlara karşı benimsediği düşmanca tavrın izleri fark edilebilir. Bu saldırgan üslup, aşağılık kompleksine saplanıp kalmış bir insanın diğer insanları küçümseyerek ve yer yer onlardan kaçarak kendisini üstün hissedebilme arzusunun ve aşağılık kompleksini telafi edebilme çabasının sonucudur.

Aşağılık kompleksiyle birlikte ortaya çıkan normal dışı davranışlar bir zincirin halkaları gibi birbirlerine eklenmiş halde bulunurlar. Onlardan herhangi birini diğerlerinden keskin çizgilerle ayırmak güçtür. Bu bağlamda insanlardan kaçma davranışı beraberinde 
anksiyeteyi getirir. "Insanlardan kaçanlar sıklıkla anksiyeteden yakınırlar. Anksiyete fazlasıyla yaygın bir özelliktir; ilk çocukluktan başlayarak yaşlanan dek bireye eşlik eder. Yaşamını belirgin ölçüde acılaştııır, onu her türlü insani temastan uzaklaştırır ve barış̧̧l bir yaşam kurma ya da dünyaya verimli katkılarda bulunma umudunu yıkar." (Adler 2004: 188). Haşim'in yaşamına bakıldığında, her zaman insanlar tarafından beğenilmeme yönünde bir endişe duyduğunu ve bu endişenin de özellikle kadınlarla olan ilişkilerinde etkili olduğu görülür. Haşim böyle düşündüğü için insanlardan uzaklaşmış ve kadınlarla hiçbir zaman sağlıklı bir ilişki kuramamıştır. Dış dünya çoğu zaman onun için bir korku kaynağı olmuştur. Anksiyete zaman zaman utangaçlık biçiminde de ortaya çıkabilir.

\begin{abstract}
"Utangaçlık anksiyetenin daha hafif ama eşit ölçüde önemli bir biçimidir; anksiyeteyle ilgili olarak söylemiş olduklarımız utangaçlık için de geçerlidir. Utangaç çocukları hangi ilişki içerisine sokarsanız sokun utangaçlıkları her zaman temaslardan kaçınmalarını ya da temas kurulduğunda bunu kesmelerini sağlayacaktır. Aşă̆glık ve başkalarından farklı olma duygusu bu çocukların temas kurmaktan zevk almasını engeller. Utangaçlık kendilerini bekleyen her görevin özellikle güç olduğunu hisseden, bir şey başarma yeteneklerine güveni olmayan insanların bir özeliğidir." (Adler 2004: 190-191)
\end{abstract}

Utangaçlık sosyal Ahmet Haşim'in ilişkilerini etkileyen bir kişilik özelliğidir. Nitekim Haşim utangaçlı̆̆ı nedeniyle insanlardan uzak durur.

Yakup Kadri'nin, Haşim hakkında anlattıklarından yola çıkarak utangaçlık duygusunun özellikle onun kadınlarla ilişkilerini şekillendirdiği görülebilir. Haşim, İzmir'de kendileriyle aynı otelde kalan bir İtalyan hanıma âşı olur, fakat bu hanımı öylesine ulaşılmaz bulur ki yanına yaklaşıp onunla konuşmaya bir türlü cesaret edemez. Ortak arkadaşlarından birisi kendisini bu hanımla tanıştıracak olduğunda ise ortalıktan kaybolur (Karaosmanoğlu 2004: 17). Anlatılan bu olayda Haşim'in kendine olan güvensizliği, kadınları aşağılama şeklinde değil, utangaçlık ve insanlardan kaçma biçiminde ortaya çıkmıştır. Bu durum aslında aşağılık kompleksinin birbirinden farklı görünümlerde ortaya çıktığının fakat aynı zamanda bu görünümlerin birbirleriyle bağlantılı olduğunun göstergesidir.

Ahmet Haşim'in yetiştirilme şartlarından, anne ve babasıyla olan iletişiminden, kadınlarla olan ilişkisine uzanan bu süreç hakkında bir değerlendirme yapılacak olursa, ilk olarak kişinin çocukluğunun onun tüm yaşamı üzerindeki güçlü etkisine değinmek gerekir. Haşim bir yandan annesinin yakın ilgisi ve yoğun sevgisi altında büyürken bir yandan da babasının mesafeli tutumuyla çevrelenmiştir. Haşim'in getirdiği aşağılık duygusundan kurtulabilmesi ve kendisini değerli hissedebilmesi için hem anne hem de baba figürlerinin tutarlı tavırlarıyla desteklenmesi gerekirdi. Oysa anne ve babasının tutarsız tavırları onu annesine yaklaştırmış ve annesini, Haşim için fiziksel ve duygusal ihtiyaçların giderildiği bir sığınak haline getirmiştir. Böylelikle aşağılık duygusu aşağılık kompleksine dönüşerek, ilerleyen yıllarda kibir, kıskançlık, tiksinti, insanlardan kaçma, anksiyete, çekingenlik gibi davranışlar ve duygular şeklinde görülmeye devam etmiştir. Bu durum, onun özellikle kadınlarla olan ilişkilerinde etkili olmuş, çoğunlukla onlardan nefret etmesine ve kaçmasına yol açmıştır. Çünkü Haşim, yaşamı boyunca karşısına çıkan kadınlarda ya annesini aramış ya da içten içte kendisini onlara lâyık bulmamıştır. Bu arayış onun şiirlerinde anneye ve hayalî sevgiliye duyulan özlem şeklinde kendisini gösterir. Ahmet Haşim, özellikle ilk şiirlerinin yer aldığı, 1908-1909 yılları arasında Resimli Kitap dergisinde yayımlanan on iki 
şiirlik Şi'r-i Kamer serisinde annesi ile geçirdiği günleri sıkça anar. Haşim Hasta İken isimli şiirinde annesiyle kendisini şu dizelerle anlatır:

"Bir vâlide, bir zevc-i mükedder, sonra mübhem

Bir ince çocuk çehresi-ben-muzlim ü ebkem,

Bî-his uzanan hastayı durmuş düşünürken,

Akşam mütemadi dolarak pencerelerden

Vermişti o sâkin odannn hüznüne bir reng,

Bir reng-i küdûret ki eder bizleri dil-teng." (2010: 111)

Şi'r-i Kamer serisinde yer alan Çıktığın Geceler, O, Sensiz, Hazan ve Nehir Üzerinde isimli şiirlerinde de hasta, solgun bir kadın şeklinde betimlenen anne imgesi ve ona eşlik eden bir çocuk yer alır. Bazı şiirlerinde ise anne ve sevgili imgeleri iç içe geçer veya ayrı şekillerde görülür. Ahmet Haşim, O Belde isimli şiirinde kadını, sevgilinin dışında kız kardeş olarak da değerlendirir.

\author{
"Denizlerden \\ Esen bu ince hevâ saçlarınla eğlensin. \\ Bilsen \\ Melâl-i hasret ü gurbetle ufk-ı şâma bakan \\ Bu gözlerinle, bu hüznünle sen ne dilbersin! \\ (...) \\ O belde? \\ Durur menâtık-ı dûşize-i tahayyülde; \\ Mâî bir akşam \\ Eder üstünde daima ârâm; \\ Eteklerde deniz \\ Döker ervaha bir sükût-ı menâm. \\ Kadınlar orda güzel, ince, saf, leylîdir, \\ Hepsinin gözlerinde hüznün var \\ Hepsi hemşiredir veyahut yâr;" (2014: 154)
}

O Belde isimli şiirde hayali kurulan o uzak ülkede gözleri hüzünle dolu, güzel kadınlar vardır. Buradaki hüzün, Haşim'in annesini çağrıştırsa da asıl üzerinde durulması gereken nokta şairin anlattığı bu yerin hayalî bir mekan olmasıdır. Ütopik bir ülke hayali, kişinin kendini yaşamdan soyutlamak isteğinin, hayattan çoğu zaman istediği zevki alamadığının ve bu zevki hayallerinde yaşamak umudunun bir göstergesidir. Nitekim Şahin'in de vurguladığı üzere, edebiyat eserlerinde mekân, yazar veya şairin mekânı şekillendiren farklı bilinçleri tarafından çeşitlenebilir. Zaman zaman ütopik mekân da bu çeşitlenmelerden biri olarak okuyucunun karşısına çıkar. Ütopik mekân çoğunlukla kaçışın ve kişinin kendisini huzurlu, mutlu hissettiği, bilinçaltındaki arzularına kavuştuğu yerdir. (2017: 325-335). Haşim'in sevme sevilme arzusu da bu hayal ülkesinde karşıllk bulmuştur. Gerçek hayatta kendisini sevmeyecekleri inancıyla türlü bahanelerle yanından uzaklaştırdığı kadınlar, sözü edilen bu beldede yarı anne yarı sevgili olarak karşısına çıkmakta ve onu sevmektedirler. Haşim'in şiirlerinde dile getirdiği anne özlemi ve kendisini sevecek o hayalî sevgiliye kavuşma umudu, aşağılık kompleksi konusunda, düzyazılarındaki kadar kesin veriler sunmaz. Fakat gerçek hayattan ve kadınlardan kopuşuyla ilgili travmanın kökenleri, zaman zaman kadınlara karşı gösterdiği saldırgan tavırları ve onlar için abartılı yorumları 
konusunda ipuçları verir. Ondaki aşağılık kompleksinin bütüncül bir bakış açısıyla değerlendirebilmesini sağlar.

\section{Türkçesi Nedeniyle Yaşadığı Uyum Sorunu}

Ahmet Haşim, annesinin ölümünün ardından babasıyla birlikte İstanbul'a döner, Türkçe öğrenmesi için Nümûne-i Terakkî Mektebi'ne verilir. Türkçesini ilerlettiği bir yılın ardından Galatasaray Lisesi'ne geçiş yapar. Haşim'in, İstanbul'a geldiğinde Türkçesinin ne düzeyde olduğuna dair farklı görüşler vardır. Ayvazoğlu (2012: 44) ve Çoban (2004: 20), Haşim'in İstanbul'a geldiğinde Arapçadan başka bir dil bilmediğini söylerken, Tanpınar'ın aksi bir görüşte olduğundan bahsederler. Fakat Haşim'in özellikle lisenin ilk yıllarındaki yalnızlığı, çekingenliği, dil problemi yaşamış olma ihtimalini akla getirmektedir. Ayrıca uzun yıllar Arapça konuşulan çevrelerde büyümesi ve Türkçesini ilerletebilmesi amacıyla bir yıl süreyle Nümûne-i Terakkî Mektebi'nde eğitim görmesi de Türkçesinin zayıf olduğu ihtimalini kuvvetlendirmektedir. Dili nedeniyle yaşadığı uyum sorununa bir de arkadaşlarının ona taktıkları "Arap Haşim” lâkabı eklenince Haşim Galatasaray Lisesi'ndeki ilk yıllarını içine kapanık ve yalnız bir halde geçirir. Zaman içerisinde edebiyata duyduğu sevgi, onun yeni bir sosyal çevreye girmesini ve kendisi gibi şiirle ilgilenen insanlarla bir araya gelmesini sağlamıştır.

Ahmet Haşim'in Galatasaray Lisesi'ne başladığında Türkçesinin yetersizliği nedeniyle yaşadığı uyum sorunu, Adler'in aşağılık kompleksi kavramı ile ilişkilendirildiğinde, bu sorunun çocuğun kabul görme arzusuna sert bir darbe vurduğu fark edilir. Daha önce de bahsedildiği üzere aşağılık karmaşasının aşağılık kompleksine dönüşmeden atlatılabilmesi için çocuğun yetersizlik duygusuyla başa çıkabilmesi, yani kendi becerilerinin farkına varıp özgüvenini inşa edebilmesi gerekir. Aksi takdirde, kişi, çocukluk veya ergenlik yıllarında inşa edemediği özgüveni, sonraki yıllarda üstünlük çabasıyla, yani uyumsuz davranışlarla sağlamaya çalışacaktır. Dolayısıyla Haşim'in Türkçesi nedeniyle arkadaşlarının alaycı esprilerine maruz kalması, yeni yaşamına uyum sağlamakta zorlanması, sosyal bir çevre edinememesi onun çocukluğundan getirdiği aşağıllk kompleksini besleyip büyütmüştür. Hisar, Haşim'in okul yıllarında bazen şakacı bazense hırçın ve öfkeli olduğunu söyler (Hisar 1963: 9). Onun bu kavgacı ve hırçın halleri karakter özelliği olarak değerlendirilebileceği gibi yaşıtlarının arasında üstünlügünü kanıtlama, varlık gösterme çabası olarak da yorumlanabilir. Nitekim yetişkinlik yıllarında sosyal ilişkilerinde yaşadığı sorunlar, sadece kadınlara olan bakış açısında veya onlarla kurduğu iletişimde orta çıkmamış, arkadaşlarıyla olan ilişkisine de yansımıştır. Aslında onun okul yıllarındaki saldırgan tutumu ve bu tutumun kıskançlık, intikam alma gibi farklı görünümleri sonraki senelerde de devam etmiş ve gerek bulunduğu çevrelerde gerekse kişisel ilişkilerinde fark edilir bir hal almıştır. Tanpınar'ın onun hakkındaki “(...) ve üstelik tahammül edilmez şekilde mütearrız bu Düyun-ı Umumiye memuruyla anlaşacak nokta bulmak hakîkaten güçtü. Kald ki bir münasebetsizliğinin, yahut onun böyle sandığı bir şey, çünkü alıngandl, öbür Haşim'i, o acayip ve zalim hiddetlerin Haşim'ini meydana çıkarabilirdi." ( 1982: 34) şeklinde yaptığı değerlendirme, Haşim'in hırçın tavırlarının arkadaşları arasında da zaman zaman ortaya çıktığını gösterir. Hırçınlığının yanı sıra, arkadaşlık ilişkilerinde boş bir gurura ve intikam alma hissine kapıldığı da görülür. Hisar, onun Halit Ziya'nın yardımıyla işe girmekten rahatsızlık duyduğunu ve intikam almak için de onun aleyhine bir yazı yazdığından bahseder (1963: 31). Çünkü Ahmet Haşim, bir başkası kendisine yardım ettiğinde kendisini aciz ve beceriksiz hisseder. Yani karşıdaki kişinin yardımıyla, ruhunun derinliklerine işlemiş yetersizlik duygusu bir kez daha açığa 
çıkar, o da bu duygudan kurtulabilmek için üstünlük kurma mücadelesine girişir. Halit Ziya ile ilgili örnekte, bunu, onun aleyhine yazı yazarak yapmıştır. Adler'in yorumuyla, bu boş gururun nedeni, kendini yükseltebilmek için başkalarını küçük görme girişimidir (1994: 188). Madalyonun diğer yüzünde ise kıskançlık vardır. Haşim'i hayata karşı daha da öfkeli hale getiren bu duygu, tıpkı diğer duygular onun insanlardan uzaklaşmasına neden olur.

\begin{abstract}
"Bunların kimi, Ahmet Haşim'in mektep arkadaşı, kimi talebesi, kimi hayranı, kimi mahmisi, kimi sadece tanıdı̆̆ı idi. Birer birer yanından ayrılıp öne geçtiler. Zavallı Haşim, bir bankanın kendisine yol verilen bir memuru iken, onlar müdir-i umumiliklere kondular. Zavall Haşim, orta mekteplerde ders vereyim diye sürüm sürüm sürünürken, onlar profesör kürsülerini işgal ettiler ve o müthiş hastahı̆ını tedavi ettirmek için kısa bir Avrupa seyahati imkânı dilenirken, ciğeri beş para etmez, sırf adale ve etten mürekkep inkılap soyguncular Londra'nın, Paris'in, Berlin'in en muhteşem otellerinde, en konforlu daireleri kiralıyorlar ve en lüks su şehirlerinde rakıdan, şampanyadan yıpranmış böbreklerini en son, en pahalı kür usulleriyle tamire çalışıyorlardı. Ahmet Haşim, bunları görüyor, hissediyor ve içleniyordu." (Karaosmanoğlu 2004: 41)
\end{abstract}

Anlatılan olaylar dikkate alınınca, Ahmet Haşim'in hayata karşı olan kötümser bakış açısında haklılık payı olsa da arkadaşlarının veya tanıdıklarının mevkilerinin, yaşam tarzlarının, onu, herhangi bir insanı etkilediğinden daha fazla etkilediği görülür. Çünkü bu durum da diğer birçok örnekte olduğu gibi kendisini onların yanında daha aşağıda, daha niteliksiz hissetmesine neden olmuştur. Nitekim "Hırsın kardeşi olan kıskançlık ihmal edilmiş olma ve ayrimcllk görme duygusundan doğan ve yaşam boyu sürebilen bir özelliktir." (Adler 2004: 176). Sözü edilen bu yıkıcı duygular bir zincirin halkaları gibi birbirlerine eklemlenerek Haşim'in zaman zaman araya mesafe koyarak arkadaşlarından uzaklaşmasına "O Belde" ye sığınmasına neden olmuştur. Aslında Haşim İstanbul'a geldikten sonra karşılaştığı dil sorunu nedeniyle, sadece arkadaşlarının alaycı şakalarına konu olmamış, kendisi için oldukça yabancı olan bir çevreye ve kültüre uyum sağlamakta da gecikmiştir. Bu süreçte çocukluğundan beri karşılaştığı zorlukların üstesinden gelememe ve bunun sonucunda kendisini diğer insanlardan aşağıda görme durumu tekrar tekrar nüksetmiştir. Ne yazık ki bu durumun giderilebilmesi için yaşıtlarıyla işbirliği içerisinde hareket ederek kendi değerinin farkına varma aşamaları gerçekleşmemiştir. Dolayısıyla üstünlük kurma çabasının sonucu olan kıskançlık, saldırganlık, hırs, insanlardan kaçma gibi uyumsuz davranışlar, sadece kadınlarla olan ilişkilerinde görülmemiş, Haşim'in okul yaşamında ve arkadaşlarıyla olan iletişiminde de ortaya çıkmıştır.

\title{
3. Diş Görünüşünden Duyduğu Memnuniyetsizlik
}

Ahmet Haşim'in dış görünüşünden duyduğu memnuniyetsizlik kendisini diğer insanların yanında çirkin ve aşağıllı görmesine neden olmuştur. Aslında sıradan hatta bakışlarıyla dikkat çekici bir görünüme sahip olan Haşim, kendisinin çirkin bir insan olduğu saplantısından kurtulamamıştır. Abdülhak Şinasi Hisar onun fiziksel özelliklerini ayrıntılı bir şekilde tarif etmiştir.

"Ahmet Haşim, orta boyunlu, hafifçe karınl, beyaz ve esmer görünmekten ziyade, pembemsi tenli, biraz seyrekleşmiş, gümüşleşmiş saçlı, yüzünde Halep çıbanına benzeyen fakat çocukluğunda geçirmiş olduğu bir kazadan kalma bir yara nişanesi bulunan, gençliğinde çıkmış resimlerinde güzel görünmeyen, fakat kendisini olduğundan fazla çirkin zanneden, canlı hareketleriyle kadınların çok kere hoş buldukları bir adamdı. (...) 
Yüzünün asıl hüviyetini teşkil eden kumral ve yeşilimtırak, büyük parlak gözleriydi."

(1979: 126)

Haşim'in vücuduna göre büyük olan başı, onu tanıyanların şairin dış görünüşünü anlatırken vurguladıkları bir uzvudur. Öğrencilerinden Bedri Rahmi Eyüboğlu onu, “Orta boylu ve yelek düğmeleri arasındaki hiçbir büklüme yer vermeyen dolgun bir gövde üzerinde Hitit eserlerindeki kafalar kadar büyük ve ekspresif bir baş." (Haşim 2010: 18) sözleriyle tarif eder. Haşim'in kendisi de kafasıyla vücudunu uyumsuz bulur ki Başım isimli şiiri yazar. Bu şiirde geçen "Bîhaber gövdeme gelmiş konmuş" (2010: 89) dizesiyle de başını neredeyse kendisinden bağımsız bir varlık olarak kabul eder. Yakup Kadri, Ahmet Haşim isimli monografik çalışmasında onun fiziksel özellikleri nedeniyle kendisine duyduğu nefreti şu cümlelerle anlatır:

\begin{abstract}
"Kendisinin son derece çirkin bir adam olduğunu zannediyordu ve bu zan, ona, ilk gençlik çă̆larından son gençlik demine kadar hayatı zehreden tasalardan biri olmuştur. Bir gün demişti ki: '- Mon cher, dün gece, bu suratımın hali uykumu kaçırdı. Onu şöyle hayalimde tashih edeyim dedim. Mesela alnımı daha muntazam bir şekle soktum. Kafamı lepiska saçlarla örttüm. Yanağımdaki Halep çıbanını hazfettim. Ă̆gımı ufalttım, çenemi incelttim. Gene bir şeye benzemedi. Anladım ki, bu kafayı kökünden söküp atmaktan başka çare yok.' " (2004: 19)
\end{abstract}

Haşim ne yaparsa yapsın kendisini bir türlü beğenemez ve onun kendisine duyduğu bu nefret tüm yaşamını etkiler.

Aslında Haşim'in tek sorunu başının büyüklüğü veya yüzündeki yara izi değildir. Çoğunlukla hafif göbekli bir adam olarak tarif edilen Haşim aynı zamanda kendisini kilolu bulur. "Dün kendimi tarttırdım. Dört ay evveline nazaran birçok kilo arrtığımı haşyetle öğrendim. Bu hâl devam ederse bir sene, iki sene sonra ne olacak? Vücudumun müstakbel şekli, bana günlerin ve ay-ların karanlık ufku üzerinde, kırmızı bir ay, âteşîn bir küre hâlinde yuvarlanıyor göründü." (Haşim 2014a: 127). Haşim kendisine bakarken ona bakanların gördüğünden çok farklı bir insan görür. Onun gördüğü canlı; çirkin, şişman ve vücuduna oranla oldukça iri başıyla insandan çok bir yaratığa benzer. Bu duygunun, kendisinde yarattığı aşağılık kompleksinin bir türlü üstesinden gelemeyen Haşim, özellikle kadınlarla olan ilişkilerinde kendisini geri çeker. "Çünkü alacă̆ı kızın kendisini sevemeyeceğine önceden kanaat getirmişti ve aldatılan bir koca olmak rezaleti, ona, felâketlerin en büyü̆̈̈̈ gibi görünüyordu." (Karaosmanoğlu 2004: 19). Haşim'in dış görünüşünden duyduğu memnuniyetsizlik, Türkçesi nedeniyle yaşadığı uyum sorunuyla birlikte ondaki aşağllık kompleksini besleyen bir diğer nedendir. Bu konuda yaşadığı özgüvensizlik sadece kadınlarla olan ilişkisini değil tüm sosyal hayatını etkileyerek daha önceki başlıklarda bahsedilen uyumsuz davranışların ortaya çıkmasına neden olur. Örneğin Yakup Kadri, Haşim'in bir kadın tarafından sevilebileceğine inanmadığından olsa gerek "Bunun içindir ki, ölünceye kadar, daima yakışıklı gençleri, sevişen çiftleri kıskandı. Onlar aleyhinde en zehirli, en kötü sözleri mübah gördü." (2004: 19) sözleriyle ondaki kıskançlık ve nefrete işaret eder. Haşim'in bu tavrı diğer olaylarda olduğu gibi kendisini üstün hissetmeye duyduğu ihtiyaçtan doğmaktadır. Aksi takdirde kendisi için duyduğu nefret ve değersizlik hissi daha da artarak onu aşağıya doğru çekecektir. 


\section{SONUÇ}

Türk şiirinin kalıplarını kırmakta önemli bir rol üstlenen Ahmet Haşim'i edebiyat araştırmacıları için dikkat çekici kılan sadece saf şiire ulaşmak konusundaki arayışı değildir. Ahmet Haşim şiir anlayışıyla olduğu kadar karakteri ile de araştırmacıların ilgi alanına girmiştir. Çünkü onun standart dışı olarak tanımlanabilecek kişiliği eserlerine yansımıştır. Annesinin koruyucu sevgisi ile babasının soğuk tavrının hüküm sürdügü bir çatı altında geçen çocukluğu onda silinmeyecek izler bırakmıştır. Verem hastası annesiyle kurduğu iki kişilik dünyada annesini kaybedecek olmanın korkusuyla yaşamış, bu korkunun yarattığ1 acizlikten kurtulamamıştır. Annesiyle kurduğu bu özel bağ, onu gerçek dünyadan koparmış, yaşam karşısındaki yetersizliği ile başa çıkabilmek için yaşıtlarının bulunduğu ve becerilerini kanıtlayabildiği sosyal bir ortamdan, itici bir güçten mahrum bırakmıştır. Babasının ona karşı takındığı mesafeli tavır ondaki yetersizlik duygusunu beslemiş ve filizlenmeye fırsat bulamayan özgüvenini neredeyse yok etmiştir. Çocukluk yıllarındaki duygusal zorlanmalara ergenlik döneminden itibaren baş gösteren çirkinlik saplantısı ve İstanbul'a geldiğinde yaşadığı uyum sorunu da eklenince Haşim'deki aşağılık duygusu yerini aşağılık kompleksine bırakmıştır. Aslında bu durum kişinin ruhsal olarak kendisini koruma altına almak istemesinden kaynaklanır. Hayat karşısında kendisini yetersiz, diğer insanlar karşısında ise değersiz hissetmekten kurtulmasının tek yolu onlardan üstün olduğuna inanmasıdır. Bu noktada yetersizlik ve değersizlik duygusuyla baş edebilmesi için üstünlük çabası devreye girer. Bu çaba bir anlamda vücudun bağışıklık mekanizması gibi çalışır ve kişinin ruh sağlığını dışarıdan gelen tehditlere karşı korur. Nitekim Haşim, aşağılık kompleksi ile baş edebilmek için tiksinti, kibir, hırs, insanlardan kaçma, boş nedenlerle gurura kapılma gibi uyumsuz davranışlar geliştirir. Diğer insanlara öfkelenerek, hırslanarak veya onları küçümseyerek kendini yüceltir ve onlardan ayrıcalıklı bir yerde konumlandırır. Böylelikle onu içten içe kemiren aşağılık kompleksine karşı bir savunma sistemi geliştirmiş olur. Sözü edilen uyumsuz davranışlar onun kadınlarla olan ilişkilerini fazlasıyla etkiler. Çirkinlik saplantısının da etkisiyle kendisini hiçbir zaman sevilmeye lâyık bulmayan Haşim, kadınlara âdeta sevilmeyişinin intikamını alırcasına hınçla yaklaşır. Onları çoğu zaman küçümser ve onlarla dalga geçer. Şiirlerinde ise, düzyazılarının aksine annesiyle geçirdiği mutlu çocukluk günlerini anar veya güzel kadınların dolaştığı ütopik ülkelere kaçmak ister. Arkadaşları ile olan ilişkileri de üstünlük kurma çabasının sonucu olarak çoğunlukla çalkantılıdır. Alınganlığı, öfkesi ve tutarsız davranışları nedeniyle onlarla olan ilişkisini bir küs bir barışık sürdürür.

Sonuç olarak aşağılık kompleksi, zaman içerisinde Türk edebiyatının yaratıcı şairi Ahmet Haşim'in sanatını besleyen hatta şekillendiren damarlardan biri haline gelmiştir. Bu damar, şiirlerinde masumane ve geçmişe duyulan özlem şeklinde görülürken; düzyazılarında saldırgan bir bakış açısı eşliğinde ortaya çıkar. Fakat her iki halde de onun eserlerine nüfuz etmekte bir anahtar vazifesi görür. 


\section{SUMMARY}

Ahmet Haşim is a name at the turning point of the Turkish poetry. His struggle to achieve pure poetry introduced the Turkish poetry into a new axis, which accelerated the innovations in poetic form and language. Ahmet Haşim wrote both prose and poetry. He was a very prolific author who also produced essays, travel writings, literary criticisms, and newspaper stories. What makes Ahmet Haşim of interest to literature researchers is his influential role in the renovation of the Turkish poetry and his so-to-say extraordinary personality. His distant and abrupt manner in his relationships with friends and women, his ugly duckling complex, and his problems with communicating with women made his unusual personality a plethora of materials for literature. A psychoanalytic analysis can help both to analyze the authors' poetry through his personality and to understand his personality through his personality.

Haşim's childhood years spent with his mother's deep love and his father's distant attitude and the pains of adjusting to a new social environment after moving to İstanbul and starting Galatasaray High School were the psychological processes that fed his distant and abrupt manner in social relations in the following years of his life. To analyze and explain this process, this study used the concept of inferiority complex coined by Viennese psychiatrist Alfred Adler accepted to be the founder of individual psychology. Accordingly, every person has a sense of lack as an existential necessity. If they fail to transform this sense into an impetus using their capabilities, it turns into an inferiority complex. Because they realize their failures and helplessness against life and start to feel worthless. To cope with such feelings, they need to feel superior to other people. This situation is called the struggle for supremacy. Then, they develop aggressive attitudes such as anger, arrogance, ambition, and pride, or escape from others to feel privileged. Thus, they can overcome the feeling of incompetence strongly felt when being with other people. Ahmet Haşim was torn between his mother' protective love and his father's distant attitude in his childhood and did not manage to overcome the feeling of inferiority. Because he was neglected by his father and raised by an exaggerated love and care of his mother. Haşim was deprived of a family and social setting allowing him to self-challenge and build self-confidence. The ugly duckling complex, and the feeling of loneliness in the first years after losing his mother rubbed salt into Haşim's wounds. As a result, he developed aggressive behavior and stayed away from people to feel superior. Thus, Haşim's feeling of incompetence turned into an inferiority complex. This study attempted to assess the causes and manifestations of Ahmet Haşim's inferiority complex on the basis of his life and works and to classify them into the headings His Relationship with Women, The Adjustment Problem Due to His Turkish, and His Dissatisfaction with Physical Appearance. 


\section{KAYNAKÇA}

Adler, Adler (1994). İnsan Tabiatını Tanıma. çev. Ayda Yörükân. İstanbul: Türkiye İş Bankası Kültür Yay.

Adler, Adler (2002). Sosyal Duygunun Gelişiminde Bireysel Psikoloji. çev. Halis Özgü. İstanbul: Hayat Yay.

Adler, Adler (2004). İnsanın Doğası. çev. Ayşen Tekşen Kapkın. İstanbul: Payel Yayınevi.

Akyüz, Kenan (1985). Batı Tesirinde Türk Şiiri Antolojisi. İstanbul: İnkılâp Kitabevi.

Alptekin, Turan (1985). Ahmet Haşim Hayatı Sanatı ve Eserleri. İstanbul. Kastaş Yay.

Ayvazoğlu, Beşir (2012). Ömrüm Benim Bir Ateşti Ahmet Hâşsim'in Hayatı, Sanatı, Estetiği,

Dramı. İstanbul: Kapı Yay.

Çoban, Ahmet (2004). Göller ve Çöller Şairi Ahmet Haşim. Ankara: Akçağ Yay.

Geçtan, Engin (1993). Çağdaş ve Normaldışı Davranışlar. İstanbul: Remzi Kitabevi.

Haşim, Ahmet (2010). Bütün Şiirleri Piyale / Göl Saatleri Diğger Şiirleri. haz. İnci EnginünZeynep Kerman. İstanbul: Dergâh Yay.

Haşim, Ahmet (2014a). Bize Göre ve İkdam'daki Diğer Yazıları. haz. İnci Enginün-Zeynep Kerman. İstanbul: Dergâh Yay.

Haşim, Ahmet (2014b). Gurabahâne-i Laklakan ve Diğer Yazıları. haz. İnci Enginün-Zeynep Kerman. İstanbul: Dergâh Yayınları.

Hisar, Abdülhak Şinasi (1963). Ahmet Haşim Şiiri ve Hayatı. İstanbul: Hilmi Kitabevi.

Hisar, Abdülhak Şinasi (1979). Ahmet Haşim - Yahya Kemal'e Veda. İstanbul: Ötüken Neşriyat. Karaosmanoğlu, Yakup Kadri (2004). Ahmet Haşim. İstanbul: İletişim Yay.

Karaosmanoğlu, Yakup Kadri (2006). Gençlik ve Edebiyat Hatıraları. İstanbul: İletişim Yay.

May, Rollo (2018). Yaratma Cesareti. çev. Alper Oysal. İstanbul: Metis Yay.

Moran, Berna (2004). Edebiyat Kuramları ve Eleştiri. İstanbul: İletişim Yay.

Şahin, Veysel (2017). Turgut Uyar'ın Şiirlerinde "Ben ve Öteki"nin Görüntü Düzeyleri. Ankara: Akçağ Yay.

Tanpınar, Ahmet Hamdi (1982). Yahya Kemal, İstanbul: Dergâh Yay.

Yetkin, Suut Kemal (1969). “Ölümünün 30. Yıldönümünde Ahmet Haşim”. Türk Dili (141): 66-73. 